
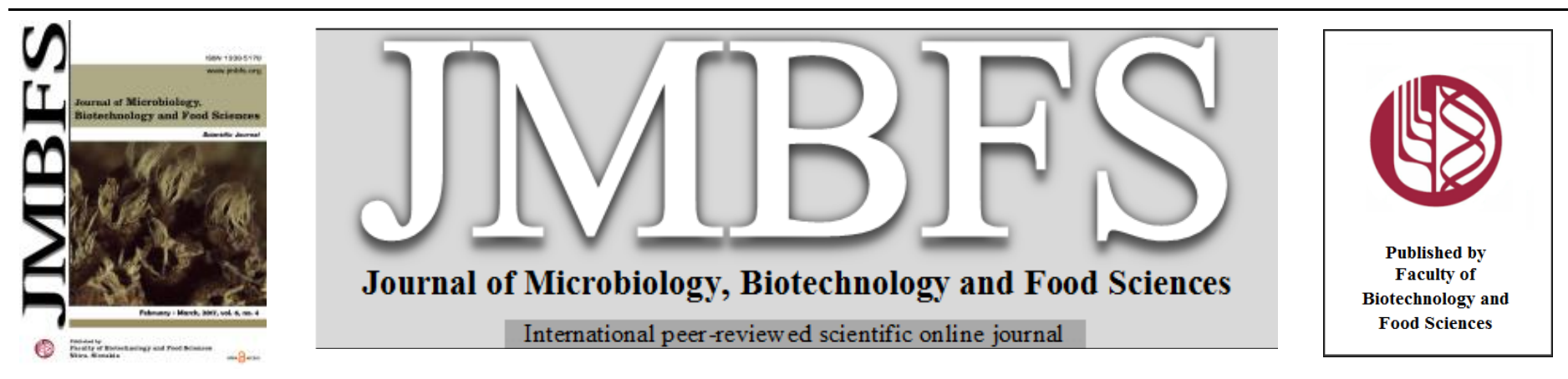

\title{
EFFECT OF NUTRITIONAL COMPOSITION ON SHELF LIFE OF CEREALS-LEGUMES BLENDED FLOURS DURING STORAGE
}

\author{
Tanzeelur Rehman ${ }^{1 *}$, Mian Kamran Sharif ${ }^{2}$, Majid Majeed $^{3}$, Muhammad Usman Khan $^{4}$,Mohammad Ali Shariati ${ }^{5}$, Vesna \\ Karapetkovska - Hristova ${ }^{6}$
}

\begin{abstract}
Address(es):
${ }^{1} \mathrm{PhD}$ Scholar, Institute of Home and Food Sciences, Government College University, Faisalabad-Pakistan.

${ }^{2}$ Assistant Professor, National Institute of Food Science and Technology, University of Agriculture, Faisalabad-Pakistan.

${ }^{3}$ National Institute of Food Science and Technology, University of Agriculture, Faisalabad-Pakistan.

${ }^{4}$ Department of Energy Systems Engineering, University of Agriculture Faisalabad,38000,Faisalabd,Pakistan

${ }^{5}$ Research Department, LLC «Science \& Education», Russia and Researcher All Russian Research Institute of Phytopathology, Moscow Region, Russia.

${ }^{6}$ Department of biotechnology, Faculty of biotechnical sciences - Bitola, University " St. KlimentOhridski" Republic of Macedonia.
\end{abstract}

*Corresponding author: trehman21@hotmail.com

doi: 10.15414/jmbfs.2017.6.4.1112-1116

\section{ARTICLE INFO}

Received 9. 11. 2016

Revised 14. 12. 2016

Accepted 5. 1.2017

Published 1. 2. 2017

Regular article

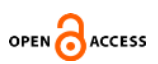

\begin{abstract}
The ubiquitous indulging of cereals and legumes all over the world gives them a momentous abode in international nutrition. The exploration of food component plays dominating ole in the nutritional assessment, shelf life and the inclusive acceptance by the end user. Maize, chickpea and soybean flours were blended uniformly @ 10, 20, 30, 40 and 50\% levels with wheat flour to prepared different compositions and stored at ambient temperature in polyethylene bags. During the fortnightly storage period of 45 days, each treatment was assessed for moisture, crude protein, crude fat, crude fiber, ash, nitrogen free extract, acidity, peroxide value and mold count. Mean squares of chemical analysis revealed significant differences due to different flour compositions and storage intervals. There was a slight increase in moisture content, total acidity, peroxide value and mold count of the composite flours whereas a decrease in protein, fiber, fat and nitrogen free extract during storage. Ash showed non-significant effect during storage. It is concluded that vacillations in temperature, relative humidity, storage circumstances, length of storage time, storage material as well as enzymatic activity made considerable nutrient losses in cereals-legumes blended flours.
\end{abstract}

Keywords: Proximate analysis, Nutrition, Storage, Cereals, Legumes, Flour

\section{INTRODUCTION}

The quality of food is centered on the natural composition and the balance between the nutrients. Chemical examination of a food sample determines the moisture, fiber, protein, fat, ash and carbohydrate reported as the percentage composition of the product. Hygroscopic nature of flour applies a strong influence on its quality, technological properties and physical characteristics. Moisture content of the flour is significant regarding shelf life, lesser the flour moisture, well its storage stability. Wheat is the indispensable food of Pakistani population and largest grain source because of its use for the preparation of various baked products. Chemical characteristics of wheat flours exhibited wide variations. In general, Pakistani wheat varieties contain on average 7.02-11.08\% moisture, $9.57-14.3 \%$ crude protein, $1.47-2.93 \%$ crude fat, $1.48-2.03 \%$ ash, 0.98 $2.68 \%$ crude fiber and 72.62-81.92\% NFE (Khan et al.,1987; Huma, 2004; Shahzadiet al.,2005; Akhtaret al., 2008). Maize/Corn is world's $3^{\text {rd }}$ leading cereal crop. Good amino acid profile of maize supports its use for supplementation to expand the protein quality of wheat based products Proximate composition of maize flours vary significantly among different varieties. Established levels of protein content ranges from $5.18 \%-8.14 \%$, fat content from $1.56-3.15 \%$, ash level $0.19-2.1 \%$, dietary fiber content $0.42-0.62 \%$ and carbohydrates 87.6-92.5\% (Shukla and Cheryan 2001; Sefa-Dedeh et al., 2004; Sandhu et al., 2007; Wu et al., 2010). Protein, fiber and fat content range of $5.2 \%, 0.5 \%$ and $2 \%$ for corn flour have been reported earlier by (Alexander, 1987).

Legumes with their therapeutic agents, occupy an important place in human nutrition whilst are important sources of food proteins, (2-3 times more than cereal grain) and are a rich source of dietary fiber (Siddiq et al., 2010). Chickpea is the $5^{\text {th }}$ most important crop worldwide. Chickpea is a good and cheap source of protein and carbohydrate. Its protein quality is better than other legumes (Kaur $\boldsymbol{e t}$ al., 2005).In world, chickpea varieties have been found to contain, on an average 7.4-7.6\% moisture, $17-29 \%$ protein, $4.5-7.1 \%$ fat, $3-9 \%$ fiber, $2.6-3.5 \%$ ash and
59.5-65.45 carbohydrate (Saleh and Tarek 2006; Chung et al., 2008; Boye et al. 2010). Among different white and whole chickpea cultivars the moisture, crude protein, crude fat, crude fiber and ash are 7.26-8.47\%, 23.06-25.18\%, 3.817.22\%, 1.14-2.78\%, 3.27-3.46\% respectively (Gomez et al., 2008). Soybean proteins, due to their good nutritional profile and excellent functionality, have become an ingredient of choice in many diverse food applications and a variety of nutritional foods and supplements. Yellow soybean contains 38.9-41.8\% protein, $18.5-21.6 \%$ fat, $7.9-9.82 \%$ moisture, $4.81-5.28 \%$ ash and $8.92-13.3 \%$ carbohydrates. In green soybean moisture, protein, fat, available carbohydrates and ash are $10.19-10.81 \%, 36.8-37.1 \%, 0.93-0.98 \%, 38.5-38.8 \%$ and $3.08-3.39 \%$ respectively (Cuenca et al., 2006). Furthermore, soybean contain $36.54 \%$, protein, $22.7 \%$ lipid, $7.36 \%$ moisture, $0.78 \%$ ash and $32.62 \%$ carbohydrates (Pednekar et al., 2010).

Molds are extensively present in nature and require minute moisture for growth than that of bacteria. Among different microorganisms molds were the most frequently detected microbes. Microorganism decreased during the milling process. Molds decreased by $88 \%$ compared with wheat before milling. In the end, products wheat flour contained molds from $10^{2}-10^{3} \mathrm{cfu} / \mathrm{g}$. The acceptable quality limit (cfu/g) for molds is $<10^{3}$ (Berghofer et al., 2003). Respiration and activity of microorganisms retarded at lower moisture content (Staudt and Zeidler, 1973). The mold contamination is also important in view of the possible mycotoxin production by a great number of mold species (Hussein \&Brasel, 2001). It has been established that molds not only cause spoilage but sometime if favorable environmental conditions exist, production of toxin occurs. The occurrence of these toxins in grains and on other food products is influenced by environmental factors during the pre-harvesting, harvesting and post-harvesting periods. Therefore, the storage conditions, length of storage time and storage materials are the key factors contributing to the stability of the flours (Akhtar $\boldsymbol{e t}$ al., 2008). Mold count in different wheat varieties during 45 days of storage ranged from 2.73-20.05 $\times 10^{2}$. Mold count of flour in tin container was higher than polypropylene bags (Huma, 2004). Mold count in composite flour samples 
at different level of storage intervals showed that mold counted at $0,15,30,45$ and 60 days were increased from $0.26 \times 10^{2}$ to $5.08 \times 10^{2} / \mathrm{g}$ (Shahzadi et al., 2005) In other studies a higher degree of mold growth was observed under ambient storage condition $\left(6.08 \times 10^{2}\right.$ colonies/g) as compared to controlled storage condition $\left(4.18 \times 10^{2} / \mathrm{g}\right)$. The length of storage time, irrespective of storage conditions demonstrated a concurrent increase in mold population. Whole whea flour samples were analyzed for mold population under two storage conditions at $0,15,30,45$, and 60 days. Higher growth $(31.44 \%)$ was observed in whole wheat flour under ambient storage condition in comparison with controlled storage condition at the termination of the storage period (Akhtar et al., 2008)

The present study was conceded to determine the effect on chemical composition and stability during storage of blended flours as well as extend the shelf life of flour by determining the proper value suitable for safe storage by analyzing the moisture, crude protein, crude fat, crude fiber, ash, nitrogen free extract, acidity, peroxide value and mold contents.

\section{MATERIAL AND METHODS}

\section{Procurement of materials}

Wheat (Triticumaestivum L.), maize/corn (Zea mays L.) soybean (Glycine max L.) and chickpea (Cicerarietinum L.) were purchased from the local market (Faisalabad, Pakistan) to make cereal-legumes blended flours.All reagents and standards were supplied by Merck (Merck KGaA, Darmstadt, Germany) and Sigma-Aldrich (Sigma-Aldrich Tokyo, Japan).

\section{Preparation of raw materials}

The raw materials were cleaned manually, to remove dirt, dust, damaged seeds, seeds of other crops and foreign matter. The particle size of wheat, maize, soybean and chickpea was reduced to fine flour through Quadrumat experimental mills.

\section{Preparation of flour blends}

Maize, chickpea and soybean flours were blended with wheat flour in different combinations to prepare composite flours, Table 1. Each treatment of composite flour was thoroughly mixed and sieved in order to achieve uniform mixing of legume flours with wheat flour and was stored at room temperature in polythene bags during a period of 45 days.

\section{Chemical analysis}

The moisture content was examined by using oven dry method, fiber using fiber tech apparatus Model: Labconco corporation, Kansas, USA), protein content was determined by using Kjeldahl's apparatus Model: Technik GmbH D-40599, Behr Labor, Germany), fat using soxhlet apparatus (Model: HT2 1045 Extraction unit, Hoganas, Sweden), ash using muffle furnace (Model: MF-1/02, PCSIR, Pakistan), total acidity, POV and mold count were determined by AACC Method No. 44-01, 32-10, 46-10, 30-10, 08-01, 02-31, 58-16 and 42-50, respectively (AACC, 2000).The nitrogen free extract was calculated according to the below expression:

NFE $\%=100-(\%$ moisture $+\%$ crude fiber $+\%$ crude protein $+\%$ crude fat $+\%$ Ash)
Table 1Treatments used to prepare composite flours.

\begin{tabular}{|c|c|c|c|c|}
\hline Treatments & $\begin{array}{c}\text { Wheat } \\
\text { Flour }(\%)\end{array}$ & $\begin{array}{c}\text { Maize } \\
\text { Flour }(\%) \\
\end{array}$ & $\begin{array}{l}\text { Chickpea } \\
\text { Flour (\%) } \\
\end{array}$ & $\begin{array}{c}\text { Soybean } \\
\text { Flour }(\%)\end{array}$ \\
\hline $\mathrm{T} 1$ & 100 & - & - & - \\
\hline $\mathrm{T} 2$ & 90 & 10 & - & - \\
\hline T3 & 80 & 20 & - & - \\
\hline $\mathrm{T} 4$ & 70 & 30 & - & - \\
\hline T5 & 60 & 40 & - & - \\
\hline T6 & 50 & 50 & - & - \\
\hline $\mathrm{T} 7$ & 90 & - & 10 & - \\
\hline $\mathrm{T} 8$ & 80 & - & 20 & - \\
\hline T9 & 70 & - & 30 & - \\
\hline $\mathrm{T} 10$ & 60 & - & 40 & - \\
\hline $\mathrm{T} 11$ & 50 & - & 50 & - \\
\hline $\mathrm{T} 12$ & 90 & - & - & 10 \\
\hline $\mathrm{T} 13$ & 80 & - & - & 20 \\
\hline $\mathrm{T} 14$ & 70 & - & - & 30 \\
\hline T15 & 60 & - & - & 40 \\
\hline T16 & 50 & - & - & 50 \\
\hline $\mathrm{T} 17$ & 90 & 3.33 & 3.33 & 3.33 \\
\hline $\mathrm{T} 18$ & 80 & 6.66 & 6.66 & 6.66 \\
\hline T19 & 70 & 10 & 10 & 10 \\
\hline $\mathrm{T} 20$ & 60 & 13.33 & 13.33 & 13.33 \\
\hline T21 & 50 & 16.66 & 16.66 & 16.66 \\
\hline
\end{tabular}

\section{Statistical analysis}

The data obtained for each parameter was subjected to statistical analysis to determine the level of significance (Analysis of variance technique) in completely randomized design as described by (Steel et al., 1997). Means were further compared through Duncan's multiple range test to determine the significant differences.

\section{RESULTS AND DISCUSSION}

It is obvious from the results that the mean squares (Table 2) for moisture, fiber, protein, fat, NFE, POV, acidity, mold content of different flour samples were significantly affected within treatments except ash that is non-significant and with storage intervals (Table 3) whereas non significantly difference were observed in the interaction between treatments and storage except protein that is significant.

Table 2Mean squares for chemical composition of different composite flour samples

\begin{tabular}{|c|c|c|c|c|c|c|c|c|c|c|}
\hline SOV & df & Moisture & Fiber & Protein & Fat & Ash & NFE & Acidity & POV & $\begin{array}{l}\text { Mold } \\
\text { count }\end{array}$ \\
\hline Treatments & 20 & $7.0418 * *$ & $0.345311^{* * *}$ & $110.688^{* * *}$ & $0.79555^{* *}$ & $0.65414 \mathrm{NS}$ & 193.436 ** & $0.036703 * *$ & $0.097571^{* *}$ & $0.4545^{* * *}$ \\
\hline Days & 3 & $10.1151^{* *}$ & $0.045515 * *$ & $0.846 * *$ & $0.06236^{* *} *$ & $0.00210 * *$ & $3.218^{* *}$ & $0.114670 * *$ & $0.726507 * *$ & $38.7022 * *$ \\
\hline $\mathrm{T} \times \mathrm{D}$ & 60 & $0.0152 \mathrm{NS}$ & $0.003502 \mathrm{NS}$ & $0.058 * *$ & $0.00089 \mathrm{NS}$ & $0.00000 \mathrm{NS}$ & $0.072 \mathrm{NS}$ & $0.002732 * *$ & $0.000963 * *$ & $0.0385 * *$ \\
\hline Error & 168 & 0.0142 & 0.002691 & 0.008 & 0.00108 & 0.00075 & 0.058 & 0.000590 & 0.000116 & 0.0052 \\
\hline
\end{tabular}

$\mathrm{NS}=$ Non-significant $(\mathrm{P}>0.05) * *=$ Highly significant $(\mathrm{P}<0.01)$

Table 3Means for the effect of storage on chemical compositions of composite flour samples

\begin{tabular}{lccccccccc}
\hline Days & $\begin{array}{c}\text { Moisture } \\
(\boldsymbol{\%})\end{array}$ & $\begin{array}{c}\text { Fiber } \\
(\boldsymbol{\%})\end{array}$ & $\begin{array}{c}\text { Protein } \\
(\boldsymbol{\%})\end{array}$ & $\begin{array}{c}\text { Fat } \\
(\boldsymbol{\%})\end{array}$ & $\begin{array}{c}\text { Ash } \\
(\boldsymbol{\%})\end{array}$ & $\begin{array}{c}\text { NFE } \\
(\boldsymbol{\%})\end{array}$ & $\begin{array}{c}\text { Acidity } \\
(\boldsymbol{\%})\end{array}$ & $\begin{array}{c}\text { POV } \\
(\mathbf{m E q} / \mathbf{K g})\end{array}$ & $\begin{array}{c}\text { Mold count } \\
(\mathbf{x 1 0 2} / \mathbf{g})\end{array}$ \\
\hline 0 & $11.33 \mathrm{~d}$ & $2.096 \mathrm{a}$ & $13.68 \mathrm{a}$ & $2.678 \mathrm{a}$ & $0.983 \mathrm{a}$ & $69.24 \mathrm{a}$ & $0.181 \mathrm{~d}$ & $0.484 \mathrm{~d}$ & $0.271 \mathrm{~d}$ \\
15 & $11.56 \mathrm{c}$ & $2.073 \mathrm{~b}$ & $13.60 \mathrm{~b}$ & $2.658 \mathrm{~b}$ & $0.983 \mathrm{a}$ & $69.14 \mathrm{~b}$ & $0.211 \mathrm{c}$ & $0.540 \mathrm{c}$ & $0.553 \mathrm{c}$ \\
30 & $11.91 \mathrm{~b}$ & $2.053 \mathrm{c}$ & $13.46 \mathrm{c}$ & $2.631 \mathrm{c}$ & $0.973 \mathrm{a}$ & $68.97 \mathrm{c}$ & $0.248 \mathrm{~b}$ & $0.640 \mathrm{~b}$ & $1.029 \mathrm{~b}$ \\
45 & $12.24 \mathrm{a}$ & $2.033 \mathrm{~d}$ & $13.43 \mathrm{~d}$ & $2.606 \mathrm{~d}$ & $0.973 \mathrm{a}$ & $68.72 \mathrm{~d}$ & $0.279 \mathrm{a}$ & $0.726 \mathrm{a}$ & $2.055 \mathrm{a}$ \\
\hline
\end{tabular}

Means sharing similar letter in a row or in a column are statistically non-significant $(\mathrm{P}>0.05)$.

\section{Moisture}

Results from various treatments showed in Table 4 significantly effect on the moisture content of composite flours. The higher moisture content $12.88 \%$ was noted in $\mathrm{T}_{16}$ while lowest value $10.38 \%$ was shown by $\mathrm{T}_{1}$.Higher increasing trend was found in wheat-maize flour blends from $\mathrm{T}_{2}$ to $\mathrm{T}_{6}$ followed by wheat-chickpea flour blends that are from $T_{7}$ to $T_{11}$ whereas the lower were found in wheat soybean flour blends from $\mathrm{T}_{12}$ to $\mathrm{T}_{16}$. All flour blends having corn, chickpea and soybean flour also showed increasing trends. It is clear from result that lower increasing trend was found in legume flour. There was an increase in moisture 
content of various flour samples because the stored sample absorbs moisture from surrounding that might be due to their hygroscopic nature and change in relative humidity during storage. The results regarding the moisture conten increased during the storage period supported the findings of (Huma 2004; Sharif 2009; Shahzadi et al., 2005)

\section{Crude Fiber}

Means for crude fiber in Table 4 exhibited that $\mathrm{T}_{10}(2.355 \%)$ showed the highest value while $\mathrm{T}_{2}$ showed the minimum value (1. 825\%).These treatments were found to be non-significant with respect to each other. Combinations in which chickpea flours are use showed the highest values of fiber followed by soybean flour blends while the minimum value was noted in corn flour blends. (Boye $\boldsymbol{e t}$ al., 2010) observed 3-9\% fiber in different chickpea varieties. Corn fiber content as narrated by (Sandhu et al., 2007) that corn fiber in different varieties varied from $0.42-0.62 \%$, whereas in corn germ the crude fiber was ranged from 2.63 $3.97 \%$ noted by (Nasir, 2009). It was noted from the results that the addition of legume four increase the value of crude fiber. Storage has a significant effect on various treatments of composite flour. Means for fiber content showed significant differences, i.e. 2.096, 2.073, 2.053 and 2.033 in $0,15,30,45$ days of storage intervals, respectively.

\section{Crude Protein}

Means for crude protein content of different composite flour in Table 4 demonstrated that $\mathrm{T}_{16}$ contained highest value $18.41 \%$, while the minimum value showed by $\mathrm{T}_{5}(9.62 \%)$. In the present study the value of protein content in different flour samples ranged from $9.62 \%-18.41 \%$. Combinations of wheat soybean flour blends showed high values for protein content followed by wheatchickpea flour blends. Wheat-corn flour blends presented low content of protein All flour combinations showed, as the quantity of flour increased, protein content increased. Previous results showed 35-40\% protein in soybean (Pednekar et al. 2010; Olaoye et al., 2006), whereas in chickpea it varied from $16.1 \%$ to $21.3 \%$ (Kaur et al. 2005). Protein content of corn ranged from $5.18 \%$ to $7.82 \%$ (Sandhu et al., 2007). Storage has significant effect Table 3 on protein content in various composite flours. Crude protein in present study decreased during 45 days of storage with accordance with (Funami et al., 2005) that with the passage of time crude protein decreased. This is due to absorption of moisture from the surrounding that accelerated the proteolytic activity of the enzymes. The enzymes are responsible for the degradation of protein during storage. It is observed by the means that there is significantly decrease in protein content during storage intervals. At $0,15,30$ and 45 days the mean value of protein content decreased to $13.68 \%, 13.60 \%, 13.46 \%$ and $13.43 \%$ respectively.

Table 4 Means for the effect of various treatments on chemical compositions of composite flour samples

\begin{tabular}{|c|c|c|c|c|c|c|c|c|c|}
\hline Treatments & $\begin{array}{c}\text { Moisture } \\
(\%)\end{array}$ & $\begin{array}{l}\text { Fiber } \\
(\%)\end{array}$ & $\begin{array}{l}\text { Protein } \\
(\%)\end{array}$ & $\begin{array}{l}\text { Fat } \\
(\%)\end{array}$ & $\begin{array}{l}\text { Ash } \\
(\%)\end{array}$ & $\begin{array}{l}\text { NFE } \\
(\%)\end{array}$ & $\begin{array}{c}\text { Acidity } \\
(\%)\end{array}$ & $\begin{array}{c}\text { POV } \\
(\mathbf{m E q} / \mathbf{K g})\end{array}$ & $\begin{array}{l}\text { Mold count } \\
\text { (x 102/g) }\end{array}$ \\
\hline $\mathrm{T} 1$ & 10.38 o & $1.993 \mathrm{f}$ & 9.851 & $2.118 n$ & 0.605 o & $75.06 \mathrm{a}$ & $0.190 \mathrm{j}$ & $0.499 \mathrm{i}$ & $0.798 \mathrm{jk}$ \\
\hline $\mathrm{T} 2$ & $10.45 \mathrm{o}$ & $1.825 \mathrm{j}$ & 9.65 no & $2.570 \mathrm{~h}$ & 0.625 no & $74.89 \mathrm{a}$ & $0.238 \mathrm{def}$ & 0.4561 & 0.7281 \\
\hline $\mathrm{T} 3$ & $10.81 \mathrm{n}$ & $1.855 \mathrm{ij}$ & $9.69 \mathrm{mno}$ & $2.695 \mathrm{ef}$ & $0.645 \mathrm{n}$ & $74.31 \mathrm{~b}$ & $0.192 \mathrm{ij}$ & 0.4641 & $0.753 \mathrm{kl}$ \\
\hline $\mathrm{T} 4$ & 11.131 & $1.895 \mathrm{hi}$ & $9.71 \mathrm{mn}$ & $2.808 \mathrm{~d}$ & $0.675 \mathrm{~m}$ & $73.78 \mathrm{c}$ & $0.258 \mathrm{~cd}$ & $0.473 \mathrm{k}$ & $1.015 \mathrm{de}$ \\
\hline T5 & $11.32 \mathrm{k}$ & $1.915 \mathrm{gh}$ & 9.62 o & $2.928 \mathrm{~b}$ & 0.7051 & $73.51 \mathrm{~d}$ & $0.265 \mathrm{c}$ & $0.482 \mathrm{j}$ & $0.815 \mathrm{ijk}$ \\
\hline T6 & $11.48 \mathrm{j}$ & $1.945 \mathrm{~g}$ & $9.75 \mathrm{~m}$ & $2.975 \mathrm{a}$ & 0.7151 & $73.14 \mathrm{e}$ & $0.348 \mathrm{a}$ & $0.489 \mathrm{j}$ & $0.934 \mathrm{fg}$ \\
\hline $\mathrm{T} 7$ & $11.03 \mathrm{~m}$ & $2.025 \mathrm{ef}$ & $13.04 \mathrm{k}$ & $2.190 \mathrm{~m}$ & $1.195 \mathrm{c}$ & $70.53 \mathrm{f}$ & $0.165 \mathrm{k}$ & $0.544 \mathrm{~h}$ & 0.7231 \\
\hline $\mathrm{T} 8$ & $11.23 \mathrm{kl}$ & $2.135 \mathrm{c}$ & $13.45 \mathrm{j}$ & 2.2881 & $1.215 \mathrm{c}$ & $69.69 \mathrm{~g}$ & $0.228 \mathrm{efg}$ & $0.566 \mathrm{~g}$ & $1.028 \mathrm{de}$ \\
\hline T9 & $11.30 \mathrm{k}$ & $2.235 \mathrm{~b}$ & $13.93 \mathrm{~h}$ & $2.353 \mathrm{k}$ & $1.245 \mathrm{~b}$ & $68.94 \mathrm{i}$ & $0.298 \mathrm{~b}$ & $0.609 \mathrm{f}$ & $1.010 \mathrm{de}$ \\
\hline $\mathrm{T} 10$ & $11.80 \mathrm{hi}$ & $2.355 \mathrm{a}$ & $14.57 \mathrm{f}$ & $2.423 \mathrm{j}$ & $1.255 \mathrm{~b}$ & $67.60 \mathrm{k}$ & $0.270 \mathrm{c}$ & $0.626 \mathrm{e}$ & $1.168 \mathrm{c}$ \\
\hline $\mathrm{T} 11$ & $11.88 \mathrm{gh}$ & $2.350 \mathrm{a}$ & $14.35 \mathrm{~g}$ & $2.538 \mathrm{i}$ & $1.295 \mathrm{a}$ & $67.59 \mathrm{k}$ & $0.335 \mathrm{a}$ & $0.629 \mathrm{e}$ & $0.885 \mathrm{gh}$ \\
\hline $\mathrm{T} 12$ & $12.50 \mathrm{~d}$ & $2.090 \mathrm{~d}$ & $17.16 \mathrm{e}$ & $2.515 \mathrm{i}$ & $0.875 \mathrm{k}$ & $64.86 \mathrm{~m}$ & 0.1331 & $0.606 \mathrm{f}$ & $0.868 \mathrm{hi}$ \\
\hline T13 & $12.58 \mathrm{~cd}$ & $2.145 \mathrm{c}$ & $17.68 \mathrm{~d}$ & $2.640 \mathrm{~g}$ & $0.895 \mathrm{k}$ & $64.07 \mathrm{n}$ & 0.213 ghi & $0.614 \mathrm{f}$ & $0.820 \mathrm{ij}$ \\
\hline $\mathrm{T} 14$ & $12.65 \mathrm{bc}$ & $2.215 \mathrm{~b}$ & $17.76 \mathrm{c}$ & $2.703 \mathrm{e}$ & $0.945 \mathrm{j}$ & $63.73 \mathrm{o}$ & $0.216 \mathrm{fgh}$ & $0.635 \mathrm{e}$ & $1.058 \mathrm{~d}$ \\
\hline $\mathrm{T} 15$ & $12.73 b$ & $2.158 \mathrm{c}$ & $18.16 \mathrm{~b}$ & $2.850 \mathrm{c}$ & $0.995 \mathrm{i}$ & $63.12 \mathrm{p}$ & $0.234 \mathrm{efg}$ & $0.670 \mathrm{~d}$ & $1.320 \mathrm{a}$ \\
\hline T16 & $12.88 \mathrm{a}$ & $2.335 \mathrm{a}$ & $18.41 \mathrm{a}$ & $2.968 \mathrm{a}$ & $1.095 \mathrm{fg}$ & $62.32 \mathrm{q}$ & $0.243 \mathrm{de}$ & $0.693 \mathrm{c}$ & $1.050 \mathrm{~d}$ \\
\hline $\mathrm{T} 17$ & $11.75 \mathrm{i}$ & $1.865 \mathrm{ij}$ & $12.99 \mathrm{k}$ & $2.645 \mathrm{~g}$ & $1.055 \mathrm{~h}$ & $69.70 \mathrm{~g}$ & $0.228 \mathrm{efg}$ & $0.671 \mathrm{~d}$ & $0.763 \mathrm{jkl}$ \\
\hline $\mathrm{T} 18$ & $11.93 \mathrm{~g}$ & $1.884 \mathrm{hi}$ & $13.06 \mathrm{k}$ & $2.673 \mathrm{f}$ & $1.085 \mathrm{~g}$ & $69.38 \mathrm{~h}$ & 0.1311 & $0.679 \mathrm{~d}$ & 0.983 ef \\
\hline T19 & $12.15 \mathrm{f}$ & $1.945 \mathrm{~g}$ & $13.41 \mathrm{j}$ & $2.783 \mathrm{~d}$ & $1.115 \mathrm{ef}$ & $68.60 \mathrm{j}$ & $0.225 \mathrm{efg}$ & $0.701 \mathrm{~b}$ & $1.205 \mathrm{bc}$ \\
\hline $\mathrm{T} 20$ & $12.40 \mathrm{e}$ & $2.045 \mathrm{e}$ & $13.79 \mathrm{i}$ & $2.913 \mathrm{~b}$ & $1.135 \mathrm{e}$ & $67.72 \mathrm{k}$ & $0.202 \mathrm{hij}$ & $0.709 \mathrm{~b}$ & $1.253 \mathrm{~b}$ \\
\hline $\mathrm{T} 21$ & $12.60 \mathrm{~cd}$ & $2.125 \mathrm{~cd}$ & $14.35 \mathrm{~g}$ & $2.938 \mathrm{~b}$ & $1.165 \mathrm{~d}$ & 66.821 & $0.214 \mathrm{gh}$ & $0.730 \mathrm{a}$ & $1.338 \mathrm{a}$ \\
\hline
\end{tabular}

\section{Crude Fat}

Means of crude fat showed in Table 4 that $\mathrm{T}_{6}(2.975 \%)$ contained highest value for fat content while the minimum value observed in $\mathrm{T}_{1}(2.118 \%)$. Fat content in different composite flours ranged from $2.118-2.975 \%$. In different flour blends, corn flour blended with wheat flour was ranked at the top in fat content followed by soybean flour blends while the minimum fat was observed in chickpea flour blends. Fat content was decreased during storage from beginning to end (Shahzadiet al., 2005). The mean Table 3 for fat content was $2.678 \%$ at 0 day, which decreased to $2.658 \%, 2.631 \%$ and $2.606 \%$ after 15,30 and 45 days of storage. The gradual decrease in fat content may be due to the development of rancidity. A moisture content higher than $12 \%$, there is a risk of fat oxidation and other chemical changes take place. Fat deterioration during storage might be due to activation of lipase enzyme which might split off the fat into free fatty acids and glycerol by the factors such as moisture, light and heat. Free fatty acid content increase during storage due to high activity of lipase.

\section{Ash}

The means for ash content of composite flour in Table 4 illustrated that ash content varies from 0.605 to $1.295 \%$. The highest amount of ash in $\mathrm{T}_{11}$ followed by $\mathrm{T}_{10}, \mathrm{~T}_{9}, \mathrm{~T}_{8}$ and $\mathrm{T}_{7}$ with ash contents of $1.295 \%, 1.255 \%, 1.245 \%, 1.215 \%$ and $1.195 \%$, respectively. Soybean was second to chickpea in term of ash content. It contained ash from 3.08\%-3.39\% revealed by (Cuenceet al., 2006). Ash content in chickpea ranged from 3.27-3.46\% among different varieties (Gomez et al., 2008). Minimum ash contents were found in corn flour combinations followed by wheat flour. Ash content of corn reported 1.24-1.26\% by (Sefa-Dedehet al. 2004). $T_{1}$ (100\% wheat) had minimum ash content because it is not fortified with corn, chickpea and soybean and same results by (Senthilet al., 2002) who noted $0.60 \%$ ash. It is clear from the results that legumes have higher ash content

\section{Nitrogen free extracts $(\mathrm{NFE})$}

The means for NFE content of composite flour in Table 4 described that $\mathrm{T}$ contained highest value $(75.06 \%)$ while lowest value was found in $\mathrm{T}_{16}(62.32 \%)$ The overall range varies from 62.32 to $75.06 \%$. The results regarding to all flour blends and wheat flour showed the highest value of NFE. Findings are in conformity with the work of (Akhtaret al., 2008) followed by corn and chickpea blends while soybean blends represented the lowest value of NFE content. With the passage of time NFE decreased significantly. At 0 days it was $69.24 \%$ followed by $69.14 \%, 68.97 \%$ and $68.72 \%$ after 15,30 and 45 days of storage, respectively. This is due to decrease in fat and protein content. The decreasing trend in flours during storage was also observed by (Huma 2004; Sharif, 2009).

\section{Acidity}

The maximum acidity was observed in $\mathrm{T}_{6}(0.348 \%)$ while the minimum in $\mathrm{T}_{18}$ $(1.31 \%) . \mathrm{T}_{1}$ showed minimum acidity $(0.130 \%)$ while maximum showed by wheat-chickpea flour blends followed by corn and soybean flour blends. Between different treatments as the concentration of different flour blends increased, increased in acidity was observed. The acidity $(0.181 \%)$ observed at 0 day, whereas increasing trend was noted at 15 days, it was $(0.211 \%)$ that increased to $(0.248 \%)$ to $(0.279 \%)$ at 30 and 45 days, respectively. The present study coincides with the results of (Anjum et al., 2003; Rehman, 2006). Increased in acidity during storage is due to increase in moisture content of the flours sample with storage, may be one of the reasons for the increase in acidity. Increase in acidity of flour during storage may be due to accumulation of linoleic and linoleic acids (Haruska and Machova 2002; Anjum et al., 2003; Shahzadi et al., 2005; Funami et al., 2005; Rehman, 2006) 


\section{Peroxide value (POV)}

Highest value of peroxide value Table 4 was observed in $\mathrm{T}_{21}(0.730 \mathrm{mEq} / \mathrm{Kg})$ while the lowest in $\mathrm{T}_{3}(0.464 \mathrm{mEq} / \mathrm{Kg})$. Highest peroxide value values were found in all flour blends combinations from $\mathrm{T}_{17}$ to $\mathrm{T}_{21}$ followed by soybean and chickpea flour blends while the lowest value in wheat-corn flour blends. The means for peroxide value in Table 3 showed that peroxide value increased from 0.484 to $0.726 \mathrm{mEq} / \mathrm{Kg}$ during 45 days of storage. Increasing trend in peroxide value was also reported by (Misfa et al., 2000; Shahzadi et al., 2005; Funami et al., 2005) this may also be due to increasing moisture content during storage.

\section{Mold count}

Mean squares for mold count of different flour samples (Table 2) showed significant variations within treatments, during storage and among interactions. The means for mold count in flour samples at different storage intervals are shown in Table 3. At initiation of the study it was found to be $0.271 \times 10^{2} / \mathrm{g}$ followed by $0.553 \times 10^{2}, 1.029 \times 10^{2}$ and $2.055 \times 10^{2} / \mathrm{g}$ after 15,30 and 45 days of storage respectively. It is obvious from the result that at 0 day minimum mold count $\left(0.110 \times 10^{2} / \mathrm{g}\right)$ in $\mathrm{T}_{17}(90 \%$ wheat $+10 \%$ soybean flour $)$ and maximum $\left(0.420 \times 10^{2} / \mathrm{g}\right)$ in $\mathrm{T}_{21}(50 \%$ wheat $+16.66 \%$ maize $+16.66 \%$ chickpea $+16.66 \%$ soybean) was found. There were increasing trend in the mold count up to 45 days. However, minimum mold count was observed $1.61 \times 10^{2} / \mathrm{g}$ in $\mathrm{T}_{1}(100 \%$ wheat) and maximum $2.6 \times 10^{2} / \mathrm{g}$ in $\mathrm{T}_{21}(50 \%$ wheat $+16.66 \%$ corn $+16.66 \%$ chickpea $+16.66 \%$ soybean) at 45 days. During storage the growth of mold ranged from $0.271 \times 10^{2}$ to $2.055 \times 10^{2} / \mathrm{g}$. Finding of (Huma, 2004; Shahzadi $\boldsymbol{e}$ al., 2005; Akhtar et al., 2008) showed increased the growth of mold during storage.

Mold count was minimum at the beginning because the $\mathrm{pH}$ of the flour does not favor their growth. During milling, mold count decreased concluded by (Berghofer et al., 2003) but in the later stage high temperature, relative humidity and hygroscopic nature of flour support mold growth which also leads to toxin development. (Akhtar et al., 2008) observed that under controlled conditions of storage mold growth can be minimized. Thus, from results if mold count increases day by day than declines in overall quality of composite flour samples.

\section{CONCLUSIONS}

The addition of legumes with cereals significantly exaggerated the chemical features of composite flour. Results exposed as the concentration of legumes flour increased with cereals flour there was increased in protein, fat, fiber and ash content but decreased in NFE. Stability of flour was also affected during storage The moisture content was increased during storage because flour absorbs moisture from surrounding due to their hygroscopic nature. Protein, fat and fiber were decreased. The decreased in protein is due to absorption of moisture from the surroundings that accelerated the proteolytic activity of the enzymes. The enzymes are responsible for the degradation of protein during storage. The gradual decrease in fat content may be due to the development of rancidity. Fat deterioration during storage might be due to activation of lipase enzyme which might split off the fat into free fatty acids and glycerol by the factors such as moisture, light and heat. Free fatty acid content increase in storage due to high activity of lipase. NFE also decreased that is due to decrease in fat and protein content. Acidity and POV increased because the decrease in fat might be due to increase in fatty acids that are due to higher lipase activity that leads to rancidity. The increased in peroxide value during present study was due to the development of rancidity. Moisture level below $12 \%$ is seemly for safe storage and minus detrimental deviations in the composition $\mathrm{f}$ blended flour. Cereal grains should not be stored above $25{ }^{\circ} \mathrm{C}$ in order to minimize nutrient losses during storage.

Acknowledgement: This research was supported by the National Institute of Food Science and Technology (NIFSAT) University of Agriculture, FaisalabadPakistan.

\section{REFRENCES}

AACC (2000).Approved Methods of American Association of Cereal Chemists, $\left(10^{\text {th }}\right.$ ed.). St. Paul, Minnesota.American Association of Cereal Chemists, Inc.

Akhtar, S., Anjum, F.M., Rehman, S.U., Sheikh, M.A. \&Farzana, K. (2008).Effect of fortification on physico-chemical and microbiological $\begin{array}{llll}\text { stability of whole wheat } \quad \text { flour.Food Chemistry. } & 110: & 113-119\end{array}$ https://doi.org/10.1016/j.foodchem.2008.01.065.

Alexander, R.J. (1987). Structure and composition.InS. A. Watson and P. E. Ramstad (Eds.).Corn Chemistry and Technology.St. Paul, MN: American Association of Cereal Chemists. 356.

Anjum, F.M., Rehman, S., Butt, M.S. \&Huma, N. (2003). Report on stability and acceptability components of the project on iron fortification of wheat flour. Ph.DThesis.Institute of Food Science and Technology, University of Agriculture, Faisalabad, Pakistan.
Berghofer, L., D.H. Ailsa, M. Di.\&Edward, J. (2003). Microbiology of wheat and flourmilling in Australia.International Journal of Food Microbiology. 85:137149. https://doi.org/10.1016/s0168-1605(02)00507-x

Boye, J., Zare, F., Pletch, A. (2010). Pulse proteins: processing, characterization, functional properties and applications in food and feed. Food Research International. 43:414-431. https://doi.org/10.1016/j.foodres.2009.09.003

Chung, H.G., Qiang, L., Ratnajothi, H., Tom, D.W., Bert, V. (2008). In vitro starch digestibility, expected glycemic index, and thermal and pasting properties of flours from pea, lentil and chickpea cultivars.Food Chemistry. 11:316-321. https://doi.org/10.1016/j.foodchem.2008.03.062

Cuenca, A.R., Suarez, M.J., Sevilla, M.D. \&Aparicio, M. (2006).Chemical composition and dietary fiber of yellow and green commercial soybeans (Glycine max). Food Chemistry. 101:1216-1222. https://doi.org/10.1016/j.foodchem.2006.03.025

Funami, T., Kataoka, Y., Omoto, T., Goto, Y., Asai, I.\& Nishinari, K. (2005). Effects ofnon-ionic polysaccharides on the gelatinization and retrogradation behavior of wheat starch. Food Hydrocolloids.19: 113.https://doi.org/10.1016/j.foodhyd.2004.04.024

Gomez, M., Bonastre, O., Cristina, M., Valentin, P., Encarnacion, F. (2008) Studies on cake quality made of wheat-chickpea flour blends. Food Science and Technology. 41:1701-1709.https://doi.org/10.1016/j.lwt.2007.11.024

Haruska, M., Machova, D. (2002). Changes of cereal flour during shortterm storage. Czech Journal of Food Science. 20: 125-30.

Huma, N. (2004). Fortification of whole wheat flour with iron for the production of unleavened flat bread (chapattis).Ph.D Thesis.National Institute of Food Science and Technology, University of Agriculture, Faisalabad, Pakistan.

Hussein, H. S., and J.M. Brasel. 2001. Toxicity, metabolism, and impact of mycotoxins on humans and animals. Toxicology. 167:101 134.https://doi.org/10.1016/s0300-483x(01)00471-1

Kaur, M., Singh, N. \&Sodhi, N.S. (2005).Physicochemical, cooking, textural and roasting characteristics of chickpea (Cicerarietinum L.) cultivars.Journal of Food Engineering. 69: 511-517.https://doi.org/10.1016/j.jfoodeng.2004.09.002.

Khan, M.A., Rashid, J. \& El-Haramein, F.J. (1987). Technological values of some Pakistani wheat varieties. Pakistan Journal of Agriculture Research 8: $121-4$.

Misfa, H., Rehman, S., Huma, N. \&Rafiq, F. (2000). Studies on wheat atta fortified with elemental iron used for chapatti production. Pakistan Journal of Food Science. 10:5-7.

Nasir, M. (2009). Characterization of maize germ from various hybrids and use of its components for value added baked products. Ph.D Thesis.National Institute of Food Science and Technology, University of Agriculture, Faisalabad, Pakistan.

Nasir, M.,Butt,M.S., Anjum,F.M., Sharif, K. \&MinhasR. (2003) . Effect of moisture on the shelf life of wheat flour. International Journal of Agriculture and Biology. 5:458-459.

Olaoye, O.A., Onilude, A.A. \&Idowu, A.O. (2006). Quality characteristics of bread produced from composite flours of wheat, plantain and soybeans. African Journal of Biotechnology. 5(11): 1102-1106.

Pednekar, M., Das, A.K., Sharma, A. \&Rajalakshmi, V. (2010). Radiation processing and functional properties of soybean (Glycine max).Radiation $\begin{array}{lll}\text { Physical Chemistry. } & \text { 79: } & \text { 490-494 }\end{array}$ https://doi.org/10.1016/j.radphyschem.2009.10.009

Rehman, Z.U. (2006). Storage effects on nutritional quality of commonly $\begin{array}{llll}\text { consumed cereals. } & \text { Food } & \text { Chemistry. } & \text { 95: }\end{array}$ https://doi.org/10.1016/j.foodchem.2004.12.017

Saleh, A.A.\&Tarek, A.E. (2006). Nutritional composition of chickpea (Cicerarietinum L.) as affected by microwave cooking and other traditional cooking methods.Journal of Food Composition and Analysis.19:806-812. https://doi.org/10.1016/j.jfca.2006.03.015

Sandhu, W.S., Singh, N. \&Malhi, N.S. (2007). Some properties of corn grains and their flours: Physicochemical, functional and chapatti-making properties of flours. Food Chemistry $\quad$ 101: 938-946. https://doi.org/10.1016/i.foodchem.2006.02.040

Sefa-Dedeh, S., Beatrice, C., Esther, S.D.\& Emmanuel, O.A. (2004).Effect of nixtamalization on the chemical and functional properties of maize.Food Chemistry. 86: 317-324. https://doi.org/10.1016/j.jfca.2006.03.015

Senthil, A., Ravi, A., Bhat, K.K. \&Seethalakshmi, M.K. (2002).Studies on the quality of fried snacks based on blends of wheat flour and soy flour.Food Quality and Preference. 13: 267-273. https://doi.org/10.1016/s0950-3293(02)00023-x

Shahzadi, N., Butt, M.S., Rehman, S.\& Sharif, K. (2005).Chemical Characteristics of Various Composite Flours.International Journal of Agriculture \& Biology. 7(1): 105-108

Shraif, M.K. (2009). Rice industrial by-products management for oil extraction and value added products. Ph.D Thesis.National Institute of Food Science and Technology, University of Agriculture, Faisalabad, Pakistan.

Shukla, R., \&Cheryan, M. (2001).Zein: the industrial protein from corn. Industrial and Crops Products. 1: 17-192. https://doi.org/10.1016/s0926 6690(00)00064-9 
Siddiq, M., Ravi, R., Harte, J.B., Dolan, K.D. (2010).Physical and functional characteristics of selected dry bean (Phaseolus vulgaris L.) flours. Food Science Technology 43: 232-237. https://doi.org/10.1016/j.lwt.2009.07.009

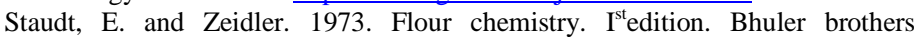
Ltd.Switzerland.

Steel, R.G.D., Torrie, J.H., Dickey, D.A. (1997).Principles and Procedures of Statistics. A biometrical Approach, 3rd Edition. McGraw Hill Book Co. Inc. New York.

Wu, M., Dong, L., Li-Jun, W., Wangb, O., Zhi-Huai, M. (2010). Rheologica properties of extruded dispersions of flaxseed-maize blend.Journal of Food Engineering. 98:480-491.https://doi.org/10.1016/j.jfoodeng.2010.01.031 